\title{
Gulf Sturgeon Movements In and Near the Mississippi River Gulf Outlet
}

James P. Kirk

June 2008

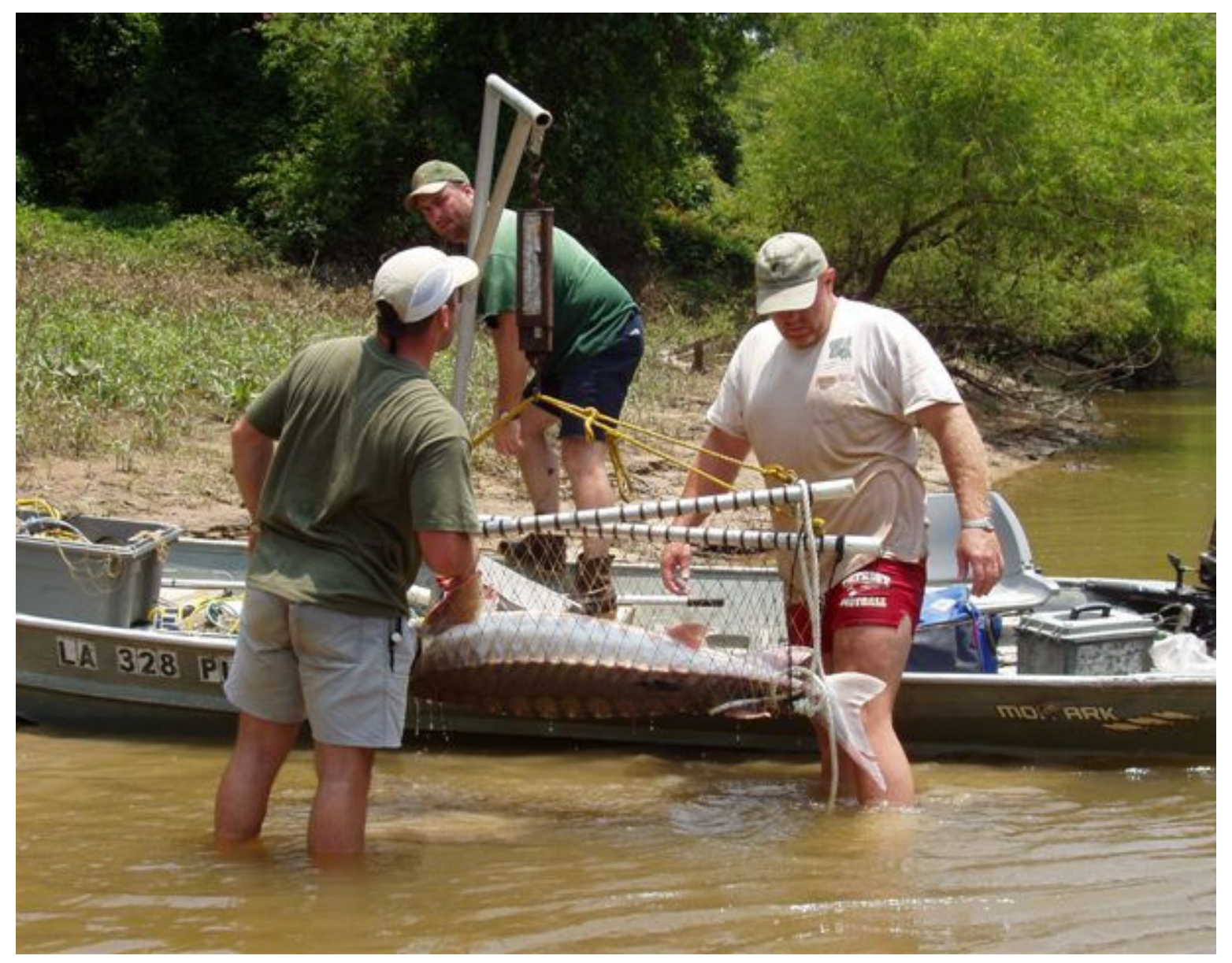




\section{Gulf Sturgeon Movements In and Near the Mississippi River Gulf Outlet}

James P. Kirk

Environmental Laboratory

U.S. Army Engineer Research and Development Center

3909 Halls Ferry Road

Vicksburg, MS 39180-6199

Final report

Approved for public release; distribution is unlimited.

Prepared for U.S. Army Engineer District, New Orleans

PO Box 60267

New Orleans, LA 70160-0267 


\begin{abstract}
The Mississippi River Gulf Outlet (MRGO) provides year-round navigation between the Mississippi River and the Gulf of Mexico. Dredging, which is periodically required to maintain navigation, may impact Gulf sturgeon. Consequently, Gulf sturgeon use of the MRGO and nearby disposal areas was monitored monthly from 2004 through 2006 using telemetry tracking. A total of 50, 40, and 20 Gulf sturgeon were captured yearly by netting in the Pearl and Bogue Chitto Rivers and fitted with transmitters. One tagged Gulf sturgeon was located in the MRGO on 19 January 2005 near marker $96\left(29^{\circ} .50 .669 \mathrm{~N} 089^{\circ} \cdot 37.643 \mathrm{~W}\right)$. Starting in June 2006, intensive gill netting of disposal sites was initiated as telemetry monitoring continued. No other Gulf sturgeon were located by telemetry nor were any caught in experimental gill nets near inland disposal sites despite more than 10,600 net meter hours of effort expended in 2006. This study thus suggests that Gulf sturgeon infrequently use the MRGO and nearby disposal areas.
\end{abstract}

DISCLAIMER: The contents of this report are not to be used for advertising, publication, or promotional purposes. Citation of trade names does not constitute an official endorsement or approval of the use of such commercial products. All product names and trademarks cited are the property of their respective owners. The findings of this report are not to be construed as an official Department of the Army position unless so designated by other authorized documents. 


\section{Contents}

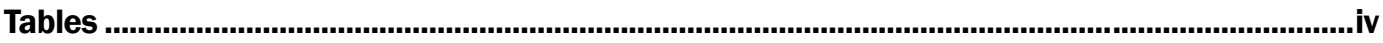

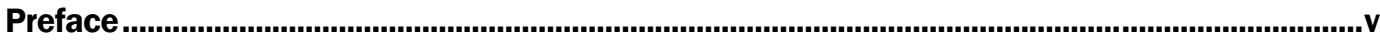

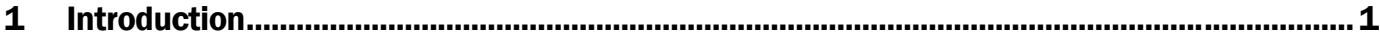

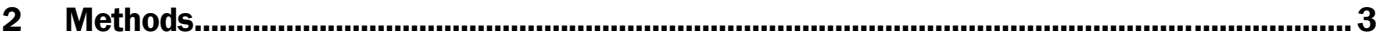

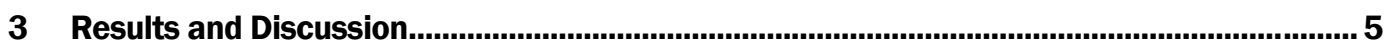

4 Implication for Corps of Engineers Channel Maintenance ….................................................. 7

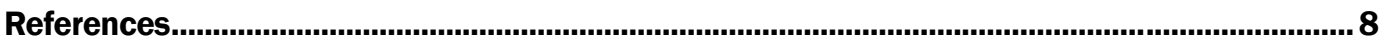

Appendix A: Summary of Gulf Sturgeon Tagged in Pearl River System, 2000-2006 ..............10

Report Documentation Page 


\section{Tables}

Table 1. Parameters used in population models and to estimate population attributes................... 4

Table 2. Estimates of the instantaneous rate of total mortality $(Z)$, estimated population size, and 95\% confidence interval for that population for the Pearl River system during

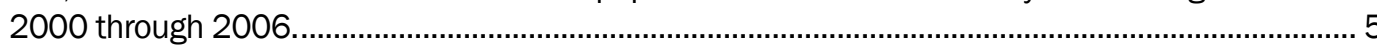




\section{Preface}

The U.S. Army Engineer District, New Orleans, provided funding for this study, which was managed by Elizabeth H. Behrens.

This report was prepared by Dr. James P. Kirk of the Aquatic Ecology and Invasive Species Branch (AEISB), Ecosystem Evaluation and Engineering Division (EEED), Environmental Laboratory (EL), U.S. Army Engineer Research and Development Center (ERDC).

Bradley Lewis, Jay Collins, William Lancaster, and Steven George of AEISB participated in field collections, as did R. Timothy Ruth, Brian McCormack, and Jeff Thompson of the Louisiana Department of Wildlife and Fisheries.

Technical reviews were provided by Dr. K. Jack Killgore and Dr. Jan J. Hoover, EL. ERDC supervision was provided by Dr. Timothy E. Lewis, Chief, AEISB; Dr. David J. Tazik, Chief, EEED; and Dr. Elizabeth C. Fleming, Director, EL.

COL Richard B. Jenkins was Commander and Executive Director of ERDC. Dr. James R. Houston was Director. 


\section{Introduction}

The Gulf of Mexico sturgeon (Acipenser oxyrinchus desotoi) or Gulf sturgeon was federally listed during 1991 (USOFR 1991). A subspecies of the Atlantic sturgeon (Vladykov 1955), this fish ranges along the Gulf coast from Florida to the Mississippi River (Grunchy and Parker 1980). Winters are spent in estuarine and marine habitats and much of the rest of the year is spent in coastal rivers (Odenkirk 1991; Foster 1993; Clugston et al. 1995; Rogillio et al. 2007).

Gulf sturgeons usually show fidelity to a single river system and movements between rivers are uncommon. Populations are therefore described on a river system basis. Some major coastal rivers remained unstudied, but Gulf sturgeon populations and recovery potential in the Pearl River system in Mississippi - Louisiana has been addressed previously (Morrow et al. 1998a, 1998b, 1999). Rogillio et al. (2007) were the first to describe the chronology of movements out of the Pearl River and to track the movements of tagged Gulf sturgeon into brackish water and marine habitats. This study described movement into brackish waters as early as September and movement into marine habitats by November. Tagged fish remained in marine waters through early March and brackish waters through June. At least one telemetry tagged Gulf sturgeon was located (prior to this study) near shipping lanes in the Mississippi River Gulf Outlet (MRGO) maintained by the U.S. Army Corps of Engineers (H. Rogillio, personal communication). Pearl River Gulf sturgeon would likely be the only population affected by such maintenance activities since no tagged Gulf sturgeon from the nearby river systems, such as the Pascagoula River, have been located.

Despite over a decade of study, much remains to be learned about limiting factors influencing population growth of Gulf sturgeon (U.S. Fish and Wildlife Service (USFWS) and GSMFC 1995; Morrow et al. 1999). A lawsuit has required the USFWS to propose critical habitats. This ruling could potentially affect Corps of Engineers responsibilities aimed at maintaining established shipping lanes in - but not necessarily limited to - the MRGO. The MRGO has been dredged, and dredged material has been disposed of at near-shore sites. Gulf sturgeon are feared susceptible to these maintenance operations. Dredging and other channel maintenance activities 
can also obstruct or alter migratory pathways, a primary concern of the USFWS in their designation of critical habitat.

Beginning in 2004, a 3-year study began to evaluate the potential occurrence of Gulf sturgeon in the MRGO. The presence of this listed species in the MRGO would require careful consideration of potential impacts of dredging and disposal operations. Gulf sturgeon use of the MRGO was intensively evaluated by telemetry and netting. To address stated concerns by the USFWS, MRGO inland disposal occupied by juveniles was sampled. In addition, population models were used to evaluate potential impacts of incidental kill caused by channel maintenance activities on long-term recruitment as part of a risk assessment. 


\section{Methods}

Gulf sturgeon were netted yearly (June through September) in the Pearl River system by biologists from the U.S. Army Engineer Research and Development Center (ERDC) and the Louisiana Department of Wildlife and Fisheries (LDWF). Fish were weighed, measured, tagged for later identification, and some fish were instrumented with radio, sonic, or dual tags for telemetry studies. This sampling (as well as sampling by the LDWF prior to 2004) provided input for estimating population attributes as well as tagged fish for monitoring movement in the MRGO.

This study approach has been used in previous Pearl River studies (Morrow et al. 1998b, 1999) to evaluate population trends, define minimum levels of total mortality leading to population growth, evaluate the impacts of commercial by catch on population growth, and to develop recovery benchmarks (Powers 1996) such as acceptable population size or total annual mortality. Age, growth, and recapture information was then used in age-structure models using MOCPOP 2.0 (Beamesderfer 1991) to ascertain population trends in the Pearl River system and simulate the potential impacts of dredging and disposal operations. Rates of recruitment based upon earlier work in the 1990s (Morrow et al. 1998b) and mortality estimates generated in this and earlier studies were used to parameterize these models (Table 1). The population size was estimated with yearly recapture information using NOREMARK (White 1996), a program that estimates abundance using capture-recapture methods and a joint hypergeometric maximum likelihood estimator. Total annual mortality was estimated using the Gulland modification (Gulland 1983) as follows:

$$
Z=k(L \infty-\text { Lmean }) /(\text { Lmean }-L c)
$$

Table 1 explains the parameters.

Gulf sturgeon tagged with sonic transmitters were available for telemetry tracking in the MRGO beginning in the Fall of 2004. At least monthly, the MRGO was monitored using a Sonotronics receiver and hydrophone. Biologists would stop every $0.7 \mathrm{~km}$ and listen for sonically tagged sturgeon from the mouth of the MRGO to about marker 6o. Water quality was 
measured with a Hydrolab ${ }^{\circledR}$ and included temperature, conductivity, dissolved oxygen, and salinity.

Table 1. Parameters used in population models and to estimate population attributes.

\begin{tabular}{|l|l|}
\hline Parameter & Definition \\
\hline$Z$ & The instantaneous rate of total mortality \\
\hline$k$ & Growth constant from the von Bertalanffy growth equation \\
\hline$L \infty$ & $\begin{array}{l}\text { Theoretical maximum fork length from the von Bertalanffy growth } \\
\text { equation }\end{array}$ \\
\hline$L m e a n$ & Mean fork length at capture \\
\hline$L C$ & Minimum fork length captured \\
\hline Model run time & 30 years \\
\hline Lifespan & Set at 25 years \\
\hline Recruitment & Set constant at age 1 or related to stock size \\
\hline Survival & A combination of values set for natural and fishing mortality \\
\hline
\end{tabular}

The USFWS raised concerns that juvenile or nonspawning adult Gulf sturgeon may reside, during warmer months, in MRGO disposal areas rather than the lower reaches of the Pearl River. This supposition is supported by earlier cooperative studies (Rogillio et al. 2007) in which juveniles were captured not far $(<20 \mathrm{~km})$ from the MRGO in the lower Pearl River system. Telemetry and limited netting were conducted monthly to determine presence of Gulf sturgeon in and nearby these disposal areas. During the summer and fall of 2006, fleets of gill nets (ten 2-m depth, experimental, monofilament nets measuring $100 \mathrm{~m}$ ) were set by ERDC and LDWF biologists in and near disposal sites to intensively sample for Gulf sturgeon. 


\section{Results and Discussion}

The Appendix, provided by the LDWF, lists approximately 180 tagged Gulf sturgeon beginning in 2000. It was judged, based upon guaranteed battery life and tag retention, that conservatively 50, 40, and 20 Gulf sturgeon would be available for tracking during 2004, 2005, and 2006, respectively. The number of tagged fish represented a substantial portion of the Pearl River population that was estimated to range between 200 through 536 during the period 2000 through 2004 (Table 2).

Table 2. Estimates of the instantaneous rate of total mortality (Z), estimated population size, and $95 \%$ confidence interval for the Gulf sturgeon population in the Pearl River system during 2000 through 2006.

\begin{tabular}{|l|l|l|l|}
\hline Year & $Z$ & $\begin{array}{l}\text { Estimate Population } \\
\text { Size }\end{array}$ & $\begin{array}{l}\text { 95\% Confidence } \\
\text { Interval }\end{array}$ \\
\hline 2000 & 0.15 & 222 & 134 to 379 \\
\hline 2001 & 0.07 & 536 & 323 to 1,031 \\
\hline 2002 & 0.05 & 246 & 199 to 317 \\
\hline 2003 & 0.04 & 200 & 54 to 345 \\
\hline 2004 & 0.05 & 277 & 210 to 434 \\
\hline 2005 & \multicolumn{2}{|l|}{ No estimate since only 18 fish were caught. } \\
\hline 2006 & 0.38 & \multicolumn{2}{|l}{} \\
\hline 2007 & 0.05 & & \\
\hline
\end{tabular}

The use of estimated population size as a recovery benchmark was suspended in 2005 because overlapping confidence intervals would not allow population trends to be detected (Table 2). However, acceptable rates of total annual mortality measured as $Z$, the instantaneous rate of total mortality (Ricker 1975), were developed by population models and selected as an alternative benchmark. These mortality estimates, also listed in Table 2, were arrived at using summer netting in the Pearl River system. Mortality appeared to be within a satisfactory range (i.e., $Z=0.16$ to 0.24 ) across a range of years except for 2006 when an estimate of $Z$ was 0.38 ; this level of mortality is outside the range that modeling in this study and earlier studies (Morrow et al. 1998b) suggests is sustainable. Gulf sturgeon were apparently displaced after Hurricane Katrina resulting in spurious 
estimates of mortality. However, mortality estimates derived during 2007 $(Z=0.05)$ suggest minimal mortality was caused by the hurricane.

After joint tagging efforts beginning in the summer of 2004, the inland portion of the MRGO was surveyed using mobile sonic monitoring. Approximately 100 soundings were made monthly in the MRGO and a total approaching 2,400 soundings were made during the period of this study. Only one Gulf sturgeon was located in the MRGO on 19 January 2005 near marker $96\left(29^{\circ} .50 .669 \mathrm{~N} 089^{\circ} \cdot 37.643 \mathrm{~W}\right)$. This juvenile fish was captured and tagged on 19 August 2004 in the East Pearl River near the National Aeronautics and Space Administration's (NASA's) John C. Stennis Space Center.

Disposal areas were routinely surveyed using mobile telemetry and periodically sampled with gill nets for Gulf sturgeon during 2004 and 2005. In order to address concerns of the USFWS concerning summering populations of juveniles in or near the disposal areas, intensive gill netting by LDWF and ERDC was conducted from May through September of 2006. A total of 10,633 net-meter-hours of netting was expended and no Gulf sturgeon were captured. Therefore, it was impractical to make generalizations about habitat utilization. 


\section{Implication for Corps of Engineers Channel Maintenance}

In summary, this was an intensive study of the potential impacts of channel maintenance in the MRGO on the Pearl River population of Gulf sturgeon. A very substantial portion of the population (perhaps as much as 25 percent) was telemetry tagged and subject to detection in the MRGO during monthly telemetry surveys. Since only one juvenile Gulf sturgeon was detected, use of the MRGO by Gulf sturgeon of any size or at any time of the year appears to be a rare event.

Summertime use of inland disposal sites was not detected despite the location of juvenile populations in the nearby lower Pearl River. As a consequence of intensive gill netting and telemetry, it is concluded that summer use in and near disposal areas is unlikely. However, it cannot be unequivocally stated that this species does not occasionally move into the MRGO. Maintenance activities that impact these fish should be monitored. 


\section{References}

Beamesderfer, R. C. P. 1991. MOCPOP 2.O: A flexible system for simulation of agestructured populations and stock-related functions. Information Report 91-4. Portland, OR: Oregon Department of Fish and Wildlife.

Clugston, J. P., A. M. Foster, and S. H. Carr. 1995. Gulf sturgeon, Acipenser oxyrinchus desotoi, in the Suwannee River, Florida, USA. In Proceedings, International Symposium on Sturgeons, Moscow, Russia, ed. A. D. Gershanovich and T. I. J. Smith, 215-224.

Foster, A. M. 1993. Movement of Gulf sturgeon, Acipenser oxyrinchus desotoi, in the Suwannee River, Florida. MS thesis, Univ. of Florida, Gainesville.

Grunchy, C. G., and B. Parker. 1980. Acipenser oxyrhyncus (Mitchill), Atlantic sturgeon. In Atlas of North American freshwater fishes, ed. D. S. Lee et al., 41. Raleigh, NC: North Carolina Museum of Natural History.

Gulland, J. A. 1983. Fish stock assessment, a manual of basic methods. FAO/Wiley series on food and agriculture, 1 . New York: Wiley.

Morrow, J. V., Jr., K. J. Killgore, J. P. Kirk, and H. E. Rogillio. 1998a. Distribution and population attributes of Gulf sturgeon in the lower Pearl River system, Louisiana. Proceedings, Annual Conference Southeastern Association of Fish and Wildlife Agencies 50(1996):79-90.

Morrow, J. V., Jr., J. P. Kirk, K. J. Killgore, H. Rogillio, and C. Knight. 1998b. Status and recovery potential of Gulf sturgeon in the Pearl River system: LouisianaMississippi. North American Journal of Fisheries Management 18:798-808.

Morrow, J. V., Jr., J. P. Kirk, K. J. Killgore, and H. E. Rogillio. 1999. Recommended enhancements to the Gulf sturgeon recovery and management plan based on Pearl River studies. North American Journal of Fisheries Management 19:11171121.

Odenkirk, J. S. 1991. Movements of Gulf of Mexico sturgeon in the Apalachicola River Florida. Proceedings, Annual Conference of the Southeastern Association of Fish and Wildlife Agencies 43(1989):230-238.

Powers, J. E. 1996. Benchmark requirements for recovering fish stocks. North American Journal of Fisheries Management 16:495-504.

Ricker, W. E. 1975. Computations and interpretation of biological statistics of fish populations. Bulletin 191. Ottawa, Canada: Fisheries Research Board of Canada.

Rogillio, H. E., R. T. Ruth, E. A. Behrens, C. N. Doolittle, W. J. Granger, and J. P. Kirk. 2007. Gulf sturgeon movements in the Pear River drainage and the Mississippi Sound. North American Journal of Fisheries Management 27:89-95.

U.S. Fish and Wildlife Service (USFWS) and Gulf States Marine Fisheries Commission (GSMFC). 1995. Gulf Sturgeon Recovery/Management Plan. Atlanta, GA. 
U.S. Office of the Federal Register (USOFR). 1991. Endangered and threatened wildlife and plants: Threatened status for the Gulf sturgeon. Federal Register 56:49,65349,658 .

Vladykov, V. D. 1955. A comparison of Atlantic sea sturgeon with a new subspecies of the Gulf of Mexico Acipenser oxyrhynchus desotoi. Journal of the Fisheries Research Board of Canada 12:754-761.

White, G. C. 1996. NOREMARK. Fort Collins, CO: Department of Fishery and Wildlife, Colorado State University. 


\section{Appendix A: Summary of Gulf Sturgeon Tagged in Pearl River System, 2000-2006}

This appendix includes a summary, provided by the Louisiana Department of Wildlife and Fisheries, of Gulf sturgeon tagged with sonic transmitters in the Pearl River system, Louisiana from 2000 to 2006. Information includes date, river location of capture, total length (TL) in inches, fork length (FL) in inches, weight (WT) in pounds, floy tag number, pit tag number (PIT \#), and sonic beep sequence.

\begin{tabular}{|c|c|c|c|c|c|c|c|c|}
\hline Date & Location & TL & FL & WT, lb & WT, g & Tag\# & PIT\# & Sequence \\
\hline 08/02/00 & Bogue Chitto River -Paige Lake & 55.0 & 48.5 & 44.00 & & 25 & 026.787 .844 & 2.7 .5 \\
\hline 08/02/00 & Bogue Chitto River -Paige Lake & 77.0 & 69.0 & 120.00 & & 164 & 005.552 .311 & 6.6 .9 \\
\hline 09/26/00 & Bogue Chitto River -Paige Lake & 72.0 & 67.0 & 100.00 & & & 001.825 .617 & 2.3.3.6 \\
\hline 09/26/00 & Bogue Chitto River -Paige Lake & 77.0 & 70.0 & 122.00 & & 164 & 005.552 .311 & 2.3.5.4 \\
\hline 09/26/00 & Bogue Chitto River -Paige Lake & 65.5 & 60.5 & 71.00 & & 263 & 019.778.292 & 2.3.6.3 \\
\hline 09/26/00 & Bogue Chitto River -Paige Lake & 62.0 & 56.5 & 64.00 & & & 015.090 .615 & 2.4.4.4 \\
\hline 09/26/00 & Bogue Chitto River -Paige Lake & 78.0 & 70.5 & 108.00 & & & 012.315 .543 & 9.7.9.7 \\
\hline $10 / 31 / 00$ & Bogue Chitto River -Paige Lake & 65.0 & 60.0 & 73.00 & & 153 & 020.082 .538 & 2.4 .9 \\
\hline $10 / 31 / 00$ & Bogue Chitto River -Paige Lake & 63.0 & 58.0 & 60.00 & & 161 & 009.822 .867 & 2.5 .8 \\
\hline $10 / 31 / 00$ & Bogue Chitto River -Paige Lake & 78.0 & 72.0 & 143.00 & & 168 & 001.320 .808 & 2.6 .7 \\
\hline $10 / 31 / 00$ & Bogue Chitto River -Paige Lake & 66.5 & 60.0 & 65.00 & & 166 & 012.040 .099 & 2.8 .4 \\
\hline $10 / 31 / 00$ & Bogue Chitto River -Paige Lake & 61.0 & 57.0 & 66.00 & & 208 & 006.596 .047 & 2.9 .3 \\
\hline $10 / 31 / 00$ & Bogue Chitto River -Paige Lake & 74.5 & 70.0 & 117.00 & & 215 & 005.552 .311 & 3.3 .9 \\
\hline $10 / 31 / 00$ & Bogue Chitto River -Paige Lake & 56.5 & 52.0 & 45.00 & & 71 & 013.851 .521 & 3.4 .12 \\
\hline $10 / 31 / 00$ & Bogue Chitto River -Paige Lake & 77.5 & 72.0 & 122.00 & & 209 & 021.046 .820 & 3.4 .8 \\
\hline $10 / 31 / 00$ & Bogue Chitto River -Paige Lake & 60.0 & 54.0 & 57.00 & & 51 & 013.543 .087 & 3.5.7 \\
\hline $10 / 31 / 00$ & Bogue Chitto River -Paige Lake & 66.0 & 60.5 & 83.00 & & 157 & 007.521 .071 & 3.6 .6 \\
\hline $10 / 31 / 00$ & Bogue Chitto River -Paige Lake & 60.0 & 54.0 & 42.00 & & 26 & 026.555 .329 & 4.4 .11 \\
\hline $10 / 31 / 00$ & Bogue Chitto River -Paige Lake & 60.5 & 54.0 & 51.00 & & 169 & 018.084.109 & 4.5 .10 \\
\hline $10 / 31 / 00$ & Bogue Chitto River -Paige Lake & 61.0 & 55.0 & 46.00 & & 211 & 015.105.107 & 4.5 .6 \\
\hline $10 / 31 / 00$ & Bogue Chitto River -Paige Lake & 52.0 & 47.0 & 36.00 & & 174 & 020.519 .070 & 5.5 .9 \\
\hline $10 / 31 / 00$ & Bogue Chitto River -Paige Lake & 56.0 & 50.5 & 39.00 & & 155 & 019.076 .564 & 5.6 .8 \\
\hline 05/02/01 & Tickfaw River & 46.0 & 41.0 & 20.00 & & 719 & 019.013.288 & 2.4.2.6 \\
\hline
\end{tabular}




\begin{tabular}{|c|c|c|c|c|c|c|c|c|}
\hline Date & Location & TL & FL & WT, lb & WT, g & Tag\# & PIT\# & Sequence \\
\hline 06/06/01 & Pascagoula Riv. @ Papermill Camp & 53.5 & 50.0 & 41.00 & & & 026.551 .622 & 2.2.4.5 \\
\hline 07/03/01 & Bogue Chitto River -Paige Lake & 62.0 & 58.0 & 74.00 & & 263 & 019.778.292 & 2.2.3.7 \\
\hline 07/10/01 & Bogue Chitto River -Paige Lake & 67.0 & 64.0 & 97.00 & & 167 & 005.312 .520 & 2.2.2.8 \\
\hline 07/10/01 & Bogue Chitto River -Paige Lake & 61.0 & 56.0 & 65.00 & & 206 & 017.311 .112 & 2.2.5.5 \\
\hline 07/24/01 & Bogue Chitto River -Page Lake & 81.0 & 75.5 & 134.00 & & 126 & 045.522 .120 & 2.2.4.6 \\
\hline 08/07/01 & Bogue Chitto River -Page Lake & 76.0 & 69.0 & 131.00 & & 133 & 045.342 .280 & 3.6.7 \\
\hline 08/07/01 & Bogue Chitto River -Page Lake & 71.5 & 66.5 & 98.00 & & 146 & 045.368 .263 & 4.4 .4 \\
\hline 08/07/01 & Bogue Chitto River -Page Lake & 66.0 & 61.0 & 80.00 & & 183 & 045.583 .121 & 5.5 .3 \\
\hline 08/07/01 & Bogue Chitto River -Page Lake & 63.0 & 58.0 & 53.00 & & 140 & 045.338 .040 & 5.5 .5 \\
\hline 08/07/01 & Bogue Chitto River -Page Lake & 67.0 & 62.0 & 69.00 & & 147 & 045.376 .013 & 5.6 .7 \\
\hline 08/22/01 & Bogue Chitto River -Paige Lake & 64.0 & 58.0 & 61.00 & & 105 & 045.383 .358 & 5.5.5.d \\
\hline 08/23/01 & Bogue Chitto River -Paige Lake & 65.0 & 57.0 & 70.00 & & 103 & 045.374 .007 & 4.4 .5 \\
\hline 08/23/01 & Bogue Chitto River -Paige Lake & 61.5 & 55.0 & 58.00 & & 111 & 045.613.314 & 5.3.6 \\
\hline 08/28/01 & Bogue Chitto River -Paige Lake & 66.5 & 62.0 & 78.00 & & 119 & 045.547 .366 & 4.7 .8 \\
\hline 08/29/01 & Bogue Chitto River -Paige Lake & 79.0 & 69.0 & 110.00 & & 108 & 017.092.094 & 3.3.4 \\
\hline 09/25/01 & Bogue Chitto River -Paige Lake & 71.5 & 67.0 & 103.00 & & 121 & 052.267.319 & 4.4 .8 \\
\hline 05/23/02 & Bogue Chitto River -Paige Lake & 73.0 & 68.5 & 100.00 & & 287 & 020.082 .538 & 6.7 .9 \\
\hline 05/23/02 & Bogue Chitto River -Paige Lake & 85.9 & 81.5 & 227.00 & & 299 & 049.810 .050 & 6.9 .9 \\
\hline 05/23/02 & Bogue Chitto River -Paige Lake & 86.5 & 78.0 & 177.00 & & 288 & 049.793 .866 & 8.9 .9 \\
\hline 06/04/02 & Bogue Chitto River -Paige Lake & 81.0 & 76.5 & 193.00 & & 286 & 049.803 .801 & 7.7.9 \\
\hline 06/04/02 & Bogue Chitto River -Paige Lake & 68.0 & 62.0 & 88.00 & & 236 & 049.772 .516 & 7.9 .9 \\
\hline 06/11/02 & Bogue Chitto River -Paige Lake & 54.5 & 49.5 & 41.00 & & & 017.122.016 & 2.5.2.5 \\
\hline $06 / 11 / 02$ & Bogue Chitto River -Paige Lake & 89.5 & 84.0 & 325.00 & & 237 & 049.118.091 & 3.7.8 \\
\hline $06 / 11 / 02$ & Bogue Chitto River -Paige Lake & 67.5 & 64.5 & 90.00 & & 248 & 049.769 .529 & 4.3 .4 \\
\hline $06 / 13 / 02$ & Bogue Chitto River -Paige Lake & 69 & 64.0 & 104.00 & & 229 & 007.571 .071 & 7.7.7 \\
\hline 06/19/02 & Bogue Chitto River -Dobsom's & 69.0 & 63.5 & 98.00 & & 249 & 048.019.309 & 6.6.7 \\
\hline 06/19/02 & Bogue Chitto River -Dobsom's & 67.0 & 62.0 & 82.00 & & 203 & 045.516 .308 & $6.8 .8 d$ \\
\hline 06/19/02 & Bogue Chitto River-Dobsom's & 69.0 & 61.0 & 82.00 & & 101 & 036.285 .074 & 6.8 .9 \\
\hline 06/20/02 & Bogue Chitto River -Dobsom's & 58 & 53 & 50.00 & & 216 & 016.023 .517 & 2.3.4.5 \\
\hline 06/25/02 & Bogue Chitto River -Dobsom's & 81 & 75 & 150.00 & & 275 & 048.262 .306 & 4.7 .8 \\
\hline 06/25/02 & Bogue Chitto River -Dobsom's & 67.0 & 62.0 & 90.00 & & 119 & 045.547 .366 & 7.8.8 \\
\hline 06/25/02 & Bogue Chitto River -Dobsom's & 68.0 & 63.0 & 93.00 & & 297 & 049.300 .529 & 8.8 .9 \\
\hline $06 / 27 / 02$ & Bogue Chitto River-Dobsom's & 76.0 & 69.5 & 126.00 & & 251 & 045.342 .280 & 4.7 .7 \\
\hline $06 / 27 / 02$ & Bogue Chitto River-Dobsom's & 62.0 & 57.0 & 64.00 & & 256 & 045.383 .358 & 5.5 .5 \\
\hline
\end{tabular}




\begin{tabular}{|c|c|c|c|c|c|c|c|c|}
\hline Date & Location & $\mathrm{TL}$ & FL & WT, lb & WT, g & Tag\# & PIT\# & Sequence \\
\hline 07/02/02 & Bogue Chitto River -Dobsom's & 67.0 & 63.0 & 90.00 & & 167 & 005.312 .520 & 2.3 .9 \\
\hline 07/17/02 & Bogue Chitto River -Dobsom's & 89.0 & 82.0 & 200.00 & & 261 & 048.014 .822 & 2.5 .6 \\
\hline 07/17/02 & Bogue Chitto River -Dobsom's & 77.5 & 69.5 & 114.00 & & 115 & 045.530 .096 & 8.8 .8 \\
\hline $08 / 27 / 02$ & Bogue Chitto River -Dobsom's & 61.0 & 56.0 & 60.00 & & 141 & 045.372 .063 & 6.6 .8 \\
\hline 08/27/02 & Bogue Chitto River -Dobsom's & 78 & 71 & 126.00 & & 124 & 052.274 .045 & $6.8 .8 d$ \\
\hline 09/10/02 & Bogue Chitto River -Pages & 67.0 & 63.0 & 90.00 & & 167 & 005.312 .520 & 2.3 .9 \\
\hline 09/11/02 & Bogue Chitto River -Pages & 85 & 79 & 171.00 & & 192 & 045.614 .884 & 5.5 .6 \\
\hline 09/16/02 & Bogue Chitto River - Pages & 74 & 70 & 168.00 & & 262 & 048.283 .825 & 2.3 .4 \\
\hline 09/16/02 & Bogue Chitto River -Pages & 75 & 69 & 121.00 & & 274 & 048.104 .379 & 6.7.7 \\
\hline 05/14/03 & Bogue Chitto River - Pages & 75 & 68.5 & 130.00 & & 918 & 048.014.359 & 6.7 .8 \\
\hline 05/21/03 & Bogue Chitto River - Pages & 74 & 66 & 106.00 & & 249 & 048.019.309 & 3.4.7.7 \\
\hline 05/29/03 & Bogue Chitto River -Dobsom's & 78.5 & 71.5 & 140.00 & & 952 & 048.011 .099 & 3.4.4.6 \\
\hline 05/29/03 & Bogue Chitto River -Dobsom's & 79 & 71 & 135.00 & & 251 & 045.342 .280 & 3.4.6.7 \\
\hline 06/02/03 & Bogue Chitto River - Pages & 70.5 & 65 & 106.00 & & 957 & 048.113 .587 & 3.4.5.5. \\
\hline 06/02/03 & Bogue Chitto River - Pages & 69.25 & 64.25 & 111.00 & & 167 & 005.312 .520 & 3.4.5.6 \\
\hline 06/02/03 & Bogue Chitto River - Pages & 73.5 & 65 & 106.00 & & 166 & 012.040 .099 & 3.4.7.6 \\
\hline 06/03/03 & Bogue Chitto River - Pages & 66 & 60.5 & 71.00 & & 211 & 015.105 .107 & 3.4.6.4 \\
\hline 06/10/03 & Bogue Chitto River - Pages & 78 & 75 & 156.00 & & 969 & 048.030 .005 & 3.4.4.7 \\
\hline 07/22/03 & Bogue Chitto River -Dobsom's & 77.5 & 70 & 126.00 & & 251 & 045.342 .280 & 3.5.4.5 \\
\hline 08/12/03 & Bogue Chitto River - Pages & 78 & 70 & 126.00 & & 906 & 005.552 .311 & 3.4.6.6 \\
\hline 08/12/03 & Bogue Chitto River -Dobsom's & 70 & 65 & 101.00 & & 967 & 048.049 .307 & 3.5.6.4 \\
\hline 08/13/03 & Bogue Chitto River - Pages & 85 & 76.5 & 180.00 & & 265 & 048.011 .884 & 3.5.7.4 \\
\hline 08/19/03 & Bogue Chitto River - Pages & 72 & 65 & 100.00 & & 963 & 052.267 .319 & 3.4.7.5 \\
\hline 08/20/03 & Bogue Chitto River - Pages & 73.5 & 65.5 & 111.00 & & 966 & 058.872 .107 & 3.5.4.4 \\
\hline 09/16/03 & Bogue Chitto River -Dobsom's & 73.5 & 65.5 & 108.00 & & 966 & 058.872 .107 & 3.4.6.5 \\
\hline 09/16/03 & Bogue Chitto River -Dobsom's & 87.5 & 82 & 221.00 & & 299 & 059.024 .818 & 7.7 .8 \\
\hline 09/19/03 & Bogue Chitto River - Pages & 80 & 72.5 & 122.00 & & 912 & 045.522 .120 & 3.4.4.5 \\
\hline 09/19/03 & Bogue Chitto River - Pages & 59 & 54 & 51.00 & & 915 & 058.776 .066 & 3.4.5.4 \\
\hline 09/19/03 & Bogue Chitto River - Pages & 66 & 60 & 76.00 & & & 019.778 .292 & 3.4.7.4 \\
\hline 09/24/03 & Bogue Chitto River - Pages & 77.5 & 70 & 121.00 & & 251 & 045.342 .280 & 3.6.3.6 \\
\hline 09/24/03 & Bogue Chitto River -Dobsom's & 61 & 54 & 54.00 & & 951 & 026.865 .830 & 3.6.4.5 \\
\hline $10 / 02 / 03$ & Bogue Chitto River - Pages & 70.5 & 63.5 & 100.00 & & 264 & 048.016 .627 & 3.5.6.5 \\
\hline $10 / 02 / 03$ & Bogue Chitto River - Pages & 60 & 54.5 & 59.00 & & 257 & 026.818 .123 & 3.6.4.4 \\
\hline $10 / 06 / 03$ & Bogue Chitto River -Dobsom's & 60 & 56 & 61.00 & & 994 & 059.026.126. & 3.5.6.6 \\
\hline
\end{tabular}




\begin{tabular}{|c|c|c|c|c|c|c|c|c|}
\hline Date & Location & $\mathrm{TL}$ & FL & WT, lb & WT, g & Tag\# & PIT\# & Sequence \\
\hline 10/06/03 & Bogue Chitto River - Pages & 60 & 54 & 50.00 & & 279 & 058.872 .318 & 3.5.6.7 \\
\hline 10/06/03 & Bogue Chitto River -Dobsom's & 78 & 75 & 146.00 & & 969 & 048.030 .005 & 3.5.7.6 \\
\hline 10/06/03 & Bogue Chitto River - Pages & 79 & 72 & 131.00 & & 930 & 058.634 .825 & 3.5.7.7 \\
\hline 10/07/03 & Bogue Chitto River -Dobsom's & 69.0 & 63.0 & 93.00 & & 989 & 048.057 .515 & 3.5.5.7 \\
\hline $06 / 24 / 04$ & Bogue Chitto River - Pages & 75 & 68 & 111.00 & & 913 & 048.262 .306 & 3.4.8.9 \\
\hline $06 / 24 / 04$ & Friday's ditch Upper Pearl River & 34.75 & 31.25 & 7.00 & & 946 & 058.639 .053 & 4.4.5.6 \\
\hline 07/20/04 & Bogue Chitto River - Pages & 66.75 & 61 & 86.00 & & 396 & 049.782 .619 & 3.6.4.6 \\
\hline $07 / 20 / 04$ & Bogue Chitto River - Below Pages & 72 & 67 & 114.00 & & 229 & 007.571 .071 & 3.7 .5 \\
\hline 07/20/04 & Bogue Chitto River - Pages & 74 & 65 & 106.00 & & 957 & 048.113 .587 & 5.6 .7 \\
\hline $07 / 21 / 04$ & Bogue Chitto River - Below Pages & 63 & 58 & 68.00 & & 979 & 058.327 .288 & 3.5.3.5 \\
\hline $07 / 22 / 04$ & East Pearl @ NASA & 32.5 & 29 & 5.44 & 2471 & 371 & 058.334 .534 & \\
\hline 08/10/04 & East Pearl @ NASA & 22.75 & 20.5 & 1.83 & 832 & 340 & 058.336 .805 & \\
\hline 08/11/04 & East Pearl @ NASA & 36 & 32 & 7.30 & & 927 & 058.853 .111 & \\
\hline 08/11/04 & East Pearl @ NASA & 18.5 & 16.5 & 0.88 & 398 & 31988 & 058.862 .302 & \\
\hline 08/11/04 & East Pearl @ NASA & 49 & 43.5 & 23.80 & & 950 & 059.045 .302 & 3.5.5.5 \\
\hline $08 / 11 / 04$ & Bogue Chitto River - Pages & 60.25 & 53 & 54.60 & & 374 & 017.109.078 & 3.5.5.6 \\
\hline 08/11/04 & East Pearl @ NASA & 26.5 & 23.5 & 2.74 & 1244 & 938 & 059.026 .578 & 3.6.3.7 \\
\hline 08/11/04 & East Pearl @ NASA & 45 & 39.5 & 15.20 & & 949 & 058.866 .846 & 4.4.4.4 \\
\hline $08 / 11 / 04$ & Bogue Chitto River - Pages & 47.5 & 42.75 & 22.00 & & 357 & 011.772 .085 & 4.4.4.5 \\
\hline 08/11/04 & Bogue Chitto River - Pages & 72 & 67 & 114.00 & & 229 & 007.571 .071 & 4.4 .7 \\
\hline 08/11/04 & East Pearl @ NASA & 32.75 & 28.75 & 5.49 & 2494 & 931 & 058.341 .849 & \\
\hline 08/11/04 & East Pearl @ NASA & 18.75 & 16.75 & 0.90 & 408 & 31989 & 058.342 .893 & \\
\hline 08/11/04 & East Pearl @ NASA & 34.5 & 31 & 6.00 & & 935 & 058.864 .576 & \\
\hline 08/12/04 & Bogue Chitto River - Pages & 49.5 & 43.25 & 20.40 & & 359 & 022.323 .606 & 4.4.6.5 \\
\hline 08/12/04 & East Pearl @ NASA & 21 & 18 & 1.12 & 507 & 373 & 022.058 .359 & \\
\hline 08/12/04 & East Pearl @ NASA & 18 & 15.5 & 0.75 & 342 & 375 & 022.374 .293 & \\
\hline $08 / 17 / 04$ & Bogue Chitto River - Pages & 43.5 & 39 & 16.10 & & 358 & 022.588 .322 & 4.4.4.8 \\
\hline $08 / 17 / 04$ & Bogue Chitto River - Pages & 45.5 & 40.5 & 15.70 & & 370 & 021.855 .637 & 4.4.5.7 \\
\hline $08 / 17 / 04$ & East Pearl @ NASA & 25.5 & 22.5 & 2.30 & 1042 & 360 & 022.826 .578 & \\
\hline $08 / 17 / 04$ & East Pearl @ NASA & 32.5 & 29 & 5.44 & 2471 & 371 & 058.334 .534 & \\
\hline 08/17/04 & Bogue Chitto River -Dobsom's & 65 & 59.5 & 72.00 & & 920 & 019.778.292 & \\
\hline 08/18/04 & Bogue Chitto River - Pages & 66.5 & 60 & 77.20 & & 362 & 048.078 .025 & 3.5.8.4 \\
\hline 08/19/04 & East Pearl @ NASA upper & 35.5 & 31.25 & 6.73 & 3056 & 940 & 055.839 .260 & 4.4.5.8 \\
\hline 08/19/04 & East Pearl @ NASA launch & 32.5 & 29 & 5.44 & 2471 & 371 & 058.334 .534 & \\
\hline
\end{tabular}




\begin{tabular}{|c|c|c|c|c|c|c|c|c|}
\hline Date & Location & $\mathrm{TL}$ & FL & WT, lb & WT, g & Tag\# & PIT\# & Sequence \\
\hline 08/19/04 & East Pearl @ NASA upper & 26 & 23.5 & 2.60 & 1179 & 945 & 059.031 .840 & \\
\hline 08/19/04 & Friday'sditch Pearl River & 15.5 & 13.5 & 0.53 & 242 & 31991 & & \\
\hline 08/19/04 & East Pearl @ NASA upper & 17.5 & 15.5 & 0.75 & 341 & 31990 & & \\
\hline 09/01/04 & Bogue Chitto River - Pages & 38 & 34.25 & 10.10 & & 311 & 014.279 .806 & 3.3 .5 \\
\hline 09/01/04 & Bogue Chitto River - Pages & 51 & 46.5 & 29.00 & & 927 & 022.585 .110 & 3.5.3.6 \\
\hline 09/01/04 & Bogue Chitto River - Pages & 53 & 47 & 32.60 & & 363 & 023.055 .832 & 3.5.4.6 \\
\hline 09/01/04 & East Pearl NASA & 31.0 & 27.5 & 4.74 & 2150 & 376 & 051.622 .886 & \\
\hline 09/08/04 & Bogue Chitto River -Dobsom's & 58 & 52 & 43.60 & & 368 & 072.039.379 & 3.5.5.8 \\
\hline 09/09/04 & Bogue Chitto River -Dobsom's & 68.5 & 61 & 71.30 & & 903 & 026.551 .622 & 3.5.5.9 \\
\hline 09/09/04 & Bogue Chitto River -Dobsom's & 63 & 58 & 59.50 & & 301 & 013.373 .082 & 3.5.7.9 \\
\hline 09/09/04 & Bogue Chitto River -Dobsom's & 62 & 58 & 61.30 & & 910 & 026.555 .329 & 3.5.8.7 \\
\hline 09/09/04 & East Pearl NASA upper & 17.5 & 15.25 & 0.57 & 258 & 31999 & & \\
\hline 09/09/04 & East Pearl NASA & 17.5 & 15.25 & 0.65 & 294 & 31997 & & \\
\hline 09/29/04 & Bogue Chitto River -Dobsom's & 83 & 75 & 158.50 & & 369 & 052.274 .045 & 3.5.7.5 \\
\hline 09/29/04 & Bogue Chitto River -Dobsom's & 64 & 59 & 62.75 & & 316 & 071.831 .862 & 3.5.8.5 \\
\hline $10 / 12 / 04$ & Bogue Chitto River - water fall & 67.5 & 63.0 & 80.50 & & 384 & 002.344 .606 & 3.5.8.6 \\
\hline $10 / 12 / 04$ & Bogue Chitto River - Pages & 58.5 & 53 & 48.70 & & 364 & 071.634 .335 & \\
\hline $10 / 12 / 04$ & Bogue Chitto River - Pages & 53.8 & 48.25 & 32.70 & & 351 & 072.079 .772 & \\
\hline $10 / 13 / 04$ & Bogue Chitto River - Pages & 58.5 & 53 & 48.70 & & 364 & 071.634 .335 & 3.5.6.9 \\
\hline $10 / 13 / 04$ & Bogue Chitto River - Pages & 63 & 58 & 61.00 & & 391 & 049.854 .779 & 3.5.7.8 \\
\hline $10 / 25 / 04$ & Bogue Chitto River - Pages & 60.5 & 55.5 & 42.00 & & 398 & 072.117 .831 & 3.5.6.8 \\
\hline $10 / 25 / 04$ & Bogue Chitto River - water fall & 48 & 44.0 & 23.00 & & 390 & 072.015 .513 & 4.4.5.5 \\
\hline $10 / 25 / 04$ & E. Pearl River NASA & 32 & 28 & 4.93 & 2239 & 379 & 048.123 .824 & \\
\hline $10 / 25 / 04$ & Bogue Chitto River - Pages & 62 & 57 & 68.00 & & 399 & 026.777.339 & \\
\hline $10 / 26 / 04$ & Pearl River - Mud/little Lake & 38 & 34 & 10.60 & & 371 & 071.610 .871 & \\
\hline 04/12/05 & Bogue Chitto River -Dobsom's & 48 & 43 & 28.60 & & 395 & 072.066 .556 & 3.5.3.9 \\
\hline $04 / 12 / 05$ & Bogue Chitto River - Pages & 55 & 49 & 44.50 & & 400 & 071.778 .596 & \\
\hline 04/13/05 & E. Pearl River NASA & 32 & 29 & 5.55 & 2519 & 389 & 071.545 .325 & \\
\hline 06/07/05 & E. Pearl River NASA & 25.75 & 23.25 & 2.69 & 1221 & 385 & 071.625 .351 & \\
\hline 06/08/05 & Bogue Chitto River - water fall & 56.25 & 51.75 & 48.00 & & 995 & 058.629 .098 & 3.4.9.8 \\
\hline 06/09/05 & Bogue Chitto River - Pages & 53 & 48.25 & 35.00 & & 392 & 071.840 .610 & 3.4.6.9 \\
\hline 06/09/05 & Bogue Chitto River -Dobsom's & 47.5 & 42.5 & 21.90 & & 366 & 043.616 .357 & 4.4 .5 \\
\hline 06/21/05 & Bogue Chitto River -Dobsom's & 66.5 & 61 & 74.40 & & 372 & 049.808 .354 & 3.3.7 \\
\hline 06/21/05 & Bogue Chitto River -Dobsom's & 65 & 58 & 55.70 & & 393 & 045.588 .794 & 3.4.8.6 \\
\hline
\end{tabular}




\begin{tabular}{|c|c|c|c|c|c|c|c|c|}
\hline Date & Location & TL & $\mathrm{FL}$ & WT, lb & WT, g & Tag\# & PIT\# & Sequence \\
\hline 07/14/05 & Bogue Chitto River - Pages & 57.5 & 51.75 & 41.00 & & 377 & 071.548 .549 & 3.3.3 \\
\hline 07/14/05 & Bogue Chitto River -Dobsom's & 50 & 46.5 & 26.80 & & 390 & 072.015 .513 & 3.4 .5 \\
\hline 07/14/05 & Bogue Chitto River -Dobsom's & 57 & 53 & 52.30 & & 352 & 071.861 .026 & 3.4.9.9 \\
\hline 07/14/05 & Bogue Chitto River - water fall & 52 & 46.5 & 30.30 & & 397 & 071.631 .829 & 4.3 .5 \\
\hline 07/14/05 & Bogue Chitto River - water fall & 48 & 42.5 & 23.90 & & 388 & 071.871 .518 & 4.4 .4 \\
\hline 08/17/05 & friday'sditch upper Pearl River & 32.25 & 28.25 & 5.70 & & 312 & 071.891 .111 & \\
\hline 02/14/06 & friday'sditch upper Pearl River & 34 & 30 & 6.35 & 2881 & 939 & 071.637 .376 & \\
\hline 05/17/06 & friday'sditch upper Pearl River & 24 & 22 & 2.64 & 1198 & 934 & 071.865 .535 & \\
\hline 06/12/06 & Bogue Chitto River - Pages & 65 & 59 & 74.00 & & 329 & 019.778 .292 & 4.4.7.7 \\
\hline 06/12/06 & Bogue Chitto River - Pages & 55.5 & 49.25 & 46.00 & & 346 & 072.087 .567 & 4.4 .8 .8 \\
\hline 06/12/06 & friday'sditch upper Pearl River & 43.25 & 38.75 & 18.00 & & 344 & 072.043 .089 & 6.6.6. \\
\hline 06/12/06 & Friday'sditch Pearl River & 32.25 & 28.25 & 5.70 & & 312 & 071.897 .111 & \\
\hline 06/12/06 & friday'sditch upper Pearl River & 29.5 & 25.5 & 4.14 & 1878 & 948 & 072.019 .047 & \\
\hline 06/12/06 & friday'sditch upper Pearl River & 17.5 & 16 & 0.84 & 380 & 31676 & & \\
\hline 06/12/06 & friday'sditch upper Pearl River & 19.25 & 17.25 & 1.13 & 512 & 31677 & & \\
\hline 06/12/06 & friday'sditch upper Pearl River & 19.25 & 17.25 & 1.08 & 490 & 31678 & & \\
\hline 06/14/06 & friday'sditch upper Pearl River & 38 & 34 & 9.31 & 4225 & 928 & 059.042.298 & 3.2 .7 \\
\hline 06/19/06 & friday'sditch upper Pearl River & 31 & 28.5 & 6.63 & 3009 & 302 & 071.820 .794 & \\
\hline 06/19/06 & friday'sditch upper Pearl River & 19.25 & 16.75 & 1.01 & 457 & 30930 & & \\
\hline 06/19/06 & friday'sditch upper Pearl River & 18.5 & 16.25 & 0.95 & 431 & 31949 & & \\
\hline 07/12/06 & friday'sditch upper Pearl River & 47 & 41 & 20.00 & & 313 & 071.540 .339 & 4.4.8 \\
\hline 07/12/06 & friday'sditch upper Pearl River & 80 & 75 & 155.00 & & 314 & 049.769 .529 & \\
\hline
\end{tabular}




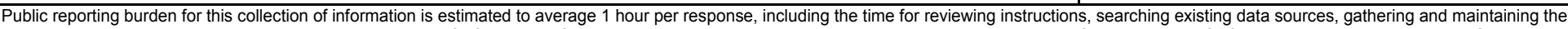

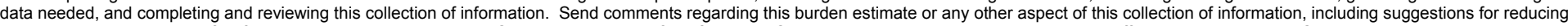

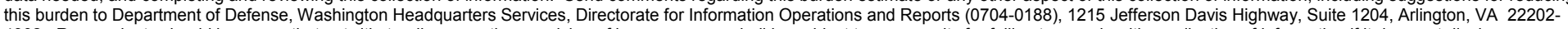

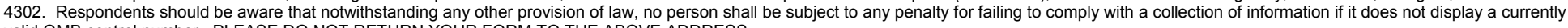
valid OMB control number. PLEASE DO NOT RETURN YOUR FORM TO THE ABOVE ADDRESS.

\section{REPORT DATE (DD-MM-YYYY) June 2008 \\ 2. REPORT TYPE \\ 4. TITLE AND SUBTITLE \\ Final report}

Gulf Sturgeon Movements In and Near the Mississippi River Gulf Outlet

\section{AUTHOR(S)}

James P. Kirk

\section{PERFORMING ORGANIZATION NAME(S) AND ADDRESS(ES)}

U.S. Army Engineer Research and Development Center

Environmental Laboratory

3909 Halls Ferry Road

3. DATES COVERED (From - To)

5a. CONTRACT NUMBER

Vicksburg, MS 39180-6199

\section{SPONSORING / MONITORING AGENCY NAME(S) AND ADDRESS(ES)}

10. SPONSOR/MONITOR'S ACRONYM(S)

U.S. Army Engineer District, New Orleans

PO Box 60267

New Orleans, LA 70160-0267

5b. GRANT NUMBER

5c. PROGRAM ELEMENT NUMBER

5d. PROJECT NUMBER

5e. TASK NUMBER

5f. WORK UNIT NUMBER

8. PERFORMING ORGANIZATION REPORT NUMBER

ERDC/EL TR-08-18

\section{DISTRIBUTION / AVAILABILITY STATEMENT}

Approved for public release; distribution is unlimited.

\section{SUPPLEMENTARY NOTES}

\section{ABSTRACT}

The Mississippi River Gulf Outlet (MRGO) provides year-round navigation between the Mississippi River and the Gulf of Mexico. Dredging, which is periodically required to maintain navigation, may impact Gulf sturgeon. Consequently, Gulf sturgeon use of the MRGO and nearby disposal areas was monitored monthly from 2004 through 2006 using telemetry tracking. A total of 50, 40, and 20 Gulf sturgeon were captured yearly by netting in the Pearl and Bogue Chitto Rivers and fitted with transmitters. One tagged Gulf sturgeon was located in the MRGO on 19 January 2005 near marker $96\left(29^{\circ} .50 .669 \mathrm{~N} 089^{\circ} .37 .643 \mathrm{~W}\right)$. Starting in June 2006 , intensive gill netting of disposal sites was initiated as telemetry monitoring continued. No other Gulf sturgeon were located by telemetry nor were any caught in experimental gill nets near inland disposal sites despite more than 10,600 net meter hours of effort expended in 2006 . This study thus suggests that Gulf sturgeon infrequently use the MRGO and nearby disposal areas.

\section{SUBJECT TERMS}

Gulf sturgeon
Monitoring

\section{SECURITY CLASSIFICATION OF:}

\begin{tabular}{|l|l|l|}
\hline a. REPORT & b. ABSTRACT & c. THIS PAGE \\
UNCLASSIFIED & UNCLASSIFIED & UNCLASSIFIED \\
\hline
\end{tabular}

Navigation

\begin{tabular}{|l|}
\hline $\begin{array}{l}\text { 17. LIMITATION } \\
\text { OF ABSTRACT }\end{array}$ \\
\end{tabular}

\begin{tabular}{|c|c}
$\begin{array}{c}\text { 18. NUMBER } \\
\text { OF PAGES }\end{array}$ & 19 \\
\cline { 2 - 2 } 21 & $19 b$ \\
&
\end{tabular}

19a. NAME OF RESPONSIBLE PERSON

19b. TELEPHONE NUMBER (include area code) 